\title{
Survival and functional capacity: three year follow up of an elderly population in hospitals and homes
}

\author{
L J DONALDSON AND C JAGGER
}

From the Department of Community Health, Leicester Royal Infirmary, Leicester LE2 7LX, UK

SUMMARY A three year mortality study was undertaken of a population of 4490 people aged 65 and over in all types of hospitals and homes provided within a defined geographical area. The rate of survival consistently fell with increasing incapacity in mobility, incontinence, washing/dressing, and feeding. The effect was independent of differences in age, sex, and duration of stay. Differences in survival between patients and residents of National Health Service hospitals (geriatric, psychiatric, acute) and homes for the elderly did not persist after adjustment for variations between populations in level of incapacity, age, and sex. An assessment based on ability to perform basic items of self care is easily undertaken and understood by staff in different settings. It allows homogeneous groups of elderly people to be identified despite a diverse range of underlying diseases and could provide the basis for planning and evaluating services and rehabilitation regimens.

An earlier study ${ }^{1}$ reported the mortality experience to one year after enumeration for an elderly population resident in the range of hopitals and homes provided by statutory, voluntary, and private agencies within a defined geographical area. Survival was found to be strongly and adversly affected by higher scores on an index of functional capacity derived from an assessment of ability to undertake basic aspects of self care.

A study of impaired people living in the community $^{2}$ has confirmed that in this setting also increasing difficulties with self care are associated with higher mortality. Measures of dependency or incapacity based on scoring systems derived by research workers do not always gain widespread acceptance or use within the service, despite assurances that may be given about their validity. In part, this must reflect the fact that such indices, although providing an apparently convenient numerical summary of the patient's status, do not convey a familiar frame of reference for professionals concerned with their care.

This study extends to three years the duration of the follow up period of the original institutional elderly population described above. Thus survival patterns may be studied in relation to the simple descriptive statements of capacity in individual items of self care that were the basis of the functional incapacity score.

\section{Methods}

A total of 4490 people aged 65 and over who were enumerated in any type of institutional care in Leicestershire on one day in December 1976 were followed up for three years to determine their mortality experience. The establishments originally surveyed included 33 NHS hospitals, 71 homes for the elderly ( 43 run by the social services department, 15 by voluntary and 13 by private agencies), 14 private nursing homes, five homes for the physically handicapped, and 10 hostels for the mentally ill or handicapped. The initial survey, in addition to recording personal and administrative details on each elderly person, contained an assessment of the extent to which they were capable of undertaking basic activities of daily living. This assessment of functional capacity in relation to mobility, urinary incontinence, faecal incontinence, washing/dressing, and feeding was based on a consensus decision by the staff immediately concerned with the care of the old person on the descriptive statement in each of the five categories that most nearly described that person. All patients and residents who had been admitted under 28 days before enumeration were excluded from the assessment of incapacity: it was reasoned that with such short durations of stay staff would not have had the opportunity to appreciate fully their level of 176 
Table 1 Percentage survival (95\% confidence limits in brackets) from time of assessment by level of mobility

\begin{tabular}{|c|c|c|c|c|c|}
\hline $\begin{array}{l}\text { Time from } \\
\text { assessment }\end{array}$ & Fully ambulant & $\begin{array}{l}\text { Ambulant except } \\
\text { stairs }\end{array}$ & $\begin{array}{l}\text { Ambulant with } \\
\text { attendant/aid }\end{array}$ & Bed fast & All levels \\
\hline $\begin{array}{l}6 \text { months } \\
1 \text { year } \\
2 \text { years } \\
3 \text { years }\end{array}$ & $\begin{array}{l}92 \cdot 0 \\
(90.4-93 \cdot 4) \\
86 \cdot 8 \\
(84.9-88 \cdot 6) \\
72 \cdot 8 \\
(70 \cdot 3-75 \cdot 2) \\
62 \cdot 4 \\
(59 \cdot 7-65 \cdot 0)\end{array}$ & $\begin{array}{l}87 \cdot 2 \\
(84 \cdot 0-89 \cdot 9) \\
76 \cdot 6 \\
(72 \cdot 7-80 \cdot 2) \\
59 \cdot 1 \\
(54 \cdot 6-63 \cdot 4) \\
44 \cdot 9 \\
(40 \cdot 5-49 \cdot 4)\end{array}$ & $\begin{array}{l}82.9 \\
(80 \cdot 9-84 \cdot 9) \\
71 \cdot 9 \\
(69 \cdot 5-74 \cdot 2) \\
52.9 \\
(50 \cdot 3-55 \cdot 5) \\
39.1 \\
(36 \cdot 6-41 \cdot 7)\end{array}$ & $\begin{array}{l}66 \cdot 0 \\
(60 \cdot 8-70 \cdot 9) \\
54 \cdot 0 \\
(48 \cdot 6-59 \cdot 3) \\
36 \cdot 2 \\
(31 \cdot 2-41 \cdot 4) \\
26 \cdot 0 \\
(21 \cdot 6-30 \cdot 8)\end{array}$ & $\begin{array}{l}85 \cdot 3 \\
(84 \cdot 1-86 \cdot 4) \\
76 \cdot 3 \\
(74 \cdot 9-77 \cdot 7) \\
59 \cdot 4 \\
(57 \cdot 8-61 \cdot 1) \\
47 \cdot 1 \\
(45 \cdot 5-48 \cdot 8)\end{array}$ \\
\hline
\end{tabular}

together with the way in which it was derived and issues of validity are discussed elsewhere. ${ }^{13}$

Copies of draft death returns applying to all Leicestershire residents and held by the Leicestershire Health Authority were searched for evidence of any members of the original institutional population dying in the three years after their initial enumeration. Details were recorded of date, cause, and place of death.

A life table analysis of mortality data was then carried out to produce survival times from the time of the initial assessment (for data on level of incapacity) and to estimate survival from the time of admission (for data on type of care). The basis of this standard life table approach is that exposure to the risk of death was grouped into a number of person-months observation. For each patient or resident it was known whether or not they died and the time from admission or enumeration. The exposure time then ran from the starting date (whether admission or enumeration) to the date of death or if they did not die to the end of the corresponding follow up period. The model takes each exposure interval and assumes a constant incidence rate of death in the interval.

The standard error of the estimates of the proportion surviving was calculated using Greenwood's formula. ${ }^{4}$ For the purposes of setting confidence intervals, a complementary log-log transformation was used to impose normality. A regression analysis of the life table was carried out using the generalised linear interactive modelling system (GLIM) ${ }^{5}$ to compare differences in survival in different groups, taking account of other factors that appreciably affected survival.

\section{Results}

The rate of survival at all time periods after assessment up to the end of the three year observation period fell with increasing incapacity. For example, two years after having been assessed as "bedfast," $36 \%$ of old people were still alive compared with $73 \%$ in the group who had been "fully ambulant" (table 1).

A similar pattern was observed for people falling into different categories with respect to urinary and faecal incontinence (tables 2 and 3). Elderly people who had been spoonfed at the time of the initial assessment had the worst survival rate over the succeeding three years of any of the incapacity groups (table 4).

In all these activities the differences in the rate of survival between the different incapacity groups remained highly significant $(p<0.001)$ after adjustment for differences in age, sex, and duration of stay using regression analysis.

Survival rates estimated to various time periods after admission differed according to which type of care the elderly person had originally been resident in (table 5). Within the three types of NHS facilities the survival rate was poorest for the population in geriatric wards and hospitals. Survival figures after admission to the non-NHS facilities (homes for the elderly and private nursing homes) were similar.

Table 2 Percentage survival (95\% confidence limits in brackets) from time of assessment by degree of urinary incontinence

\begin{tabular}{|c|c|c|c|c|c|}
\hline $\begin{array}{l}\text { Time from } \\
\text { assessment }\end{array}$ & Not incontinent & $\begin{array}{l}\text { Needed raising or } \\
\text { sending }\end{array}$ & Incontinent once & Often incontinent & All degrees \\
\hline $\begin{array}{l}6 \text { months } \\
1 \text { year } \\
2 \text { years } \\
3 \text { years }\end{array}$ & $\begin{array}{l}90 \cdot 7 \\
(89 \cdot 4-91 \cdot 9) \\
84 \cdot 1 \\
(82 \cdot 5-85 \cdot 7) \\
69 \cdot 6 \\
(67 \cdot 6-71 \cdot 6) \\
57 \cdot 3 \\
(55 \cdot 1-59 \cdot 5)\end{array}$ & $\begin{array}{l}85 \cdot 1 \\
(80 \cdot 8-88 \cdot 6) \\
74 \cdot 1 \\
(69 \cdot 1-78 \cdot 7) \\
56 \cdot 5 \\
(51 \cdot 0-61 \cdot 9) \\
43 \cdot 3 \\
(38 \cdot 0-48 \cdot 8)\end{array}$ & $\begin{array}{l}82 \cdot 3 \\
(78 \cdot 0-86 \cdot 0) \\
70 \cdot 1 \\
(65 \cdot 2-75 \cdot 0) \\
48 \cdot 2 \\
(43 \cdot 0-53 \cdot 3) \\
35 \cdot 9 \\
(31 \cdot 1-41 \cdot 0)\end{array}$ & $\begin{array}{l}73 \cdot 5 \\
(70 \cdot 4-76 \cdot 4) \\
61 \cdot 1 \\
(57 \cdot 7-64 \cdot 4) \\
41 \cdot 1 \\
(37 \cdot 8-44 \cdot 5) \\
28 \cdot 9 \\
(25 \cdot 9-32 \cdot 1)\end{array}$ & $\begin{array}{l}85 \cdot 4 \\
(84 \cdot 2-86 \cdot 5) \\
76 \cdot 5 \\
(75 \cdot 1-77 \cdot 9) \\
59 \cdot 6 \\
(58 \cdot 0-61 \cdot 2) \\
47 \cdot 3 \\
(45 \cdot 6-48 \cdot 9)\end{array}$ \\
\hline
\end{tabular}


Table 3 Percentage survival (95\% confidence limits in brackets) from time of assessment by presence of faecal incontinence

\begin{tabular}{llll}
\hline \multirow{2}{*}{$\begin{array}{l}\text { Time from } \\
\text { assessment }\end{array}$} & \multicolumn{2}{l}{ Faecal incontinence } & \\
\cline { 2 - 3 } & Absent & Present & All people \\
\hline 6 months & $88 \cdot 2$ & $72 \cdot 9$ & $85 \cdot 2$ \\
& $(86 \cdot 9-89 \cdot 3)$ & $(69 \cdot 5-76 \cdot 2)$ & $(84 \cdot 0-86 \cdot 3)$ \\
1 year & 79.9 & $60 \cdot 6$ & $76 \cdot 1$ \\
& $(78 \cdot 4-81 \cdot 4)$ & $(56 \cdot 9-64 \cdot 2)$ & $(74 \cdot 7-77 \cdot 5)$ \\
2 years & $64 \cdot 5$ & $37 \cdot 6$ & $59 \cdot 2$ \\
& $(62 \cdot 7-66 \cdot 2)$ & $(34 \cdot 1-41 \cdot 2)$ & $(57 \cdot 5-60 \cdot 8)$ \\
3 years & $51 \cdot 9$ & $25 \cdot 6$ & $46 \cdot 7$ \\
& $(50 \cdot 1-53 \cdot 8)$ & $(22 \cdot 5-28 \cdot 9)$ & $(45 \cdot 1-48 \cdot 4)$ \\
\hline
\end{tabular}

Table 4 Percentage survival (95\% confidence limits in brackets) from time of assessment by level of independence in feeding

\begin{tabular}{|c|c|c|c|c|}
\hline $\begin{array}{l}\text { Time from } \\
\text { assessment }\end{array}$ & $\begin{array}{l}\text { Not } \\
\text { supervised }\end{array}$ & $\begin{array}{l}\text { Needed } \\
\text { supervision }\end{array}$ & Spoonfed & All degrees \\
\hline 6 months & $\begin{array}{l}89.8 \\
(88.5-90.9)\end{array}$ & $\begin{array}{l}80.7 \\
(77.6-83.4)\end{array}$ & $\begin{array}{l}59 \cdot 3 \\
(53 \cdot 7-64 \cdot 7)\end{array}$ & $\begin{array}{l}85 \cdot 3 \\
(84 \cdot 1-86 \cdot 4)\end{array}$ \\
\hline 1 year & $\begin{array}{l}81 \cdot 4 \\
(79 \cdot 8-82 \cdot 9)\end{array}$ & $\begin{array}{l}71 \cdot 3 \\
(67 \cdot 9-74 \cdot 5)\end{array}$ & $\begin{array}{l}46 \cdot 4 \\
(40 \cdot 9-52 \cdot 0)\end{array}$ & $\begin{array}{l}76 \cdot 3 \\
(74 \cdot 8-77 \cdot 7)\end{array}$ \\
\hline 2 years & $\begin{array}{l}65.8 \\
(63.9-67.7)\end{array}$ & $\begin{array}{l}50 \cdot 4 \\
(46 \cdot 7-54 \cdot 1)\end{array}$ & $\begin{array}{l}29.7 \\
(24 \cdot 8-34 \cdot 9)\end{array}$ & $\begin{array}{l}59.5 \\
(57.8-61.1)\end{array}$ \\
\hline 3 years & $\begin{array}{l}53.0 \\
(51.0-55.0)\end{array}$ & $\begin{array}{l}38.9 \\
(35.4)-42 \cdot 5)\end{array}$ & $\begin{array}{l}19 \cdot 0 \\
(15 \cdot 0-23 \cdot 5)\end{array}$ & $\begin{array}{l}47 \cdot 1 \\
(45 \cdot 4-48 \cdot 7)\end{array}$ \\
\hline
\end{tabular}

Both had higher survival figures than the populations in NHS geriatric beds but not so good as the population that had originally been in acute beds. It enjoyed the most favourable figures of all types of care.

When a regression analysis model of the life table was applied to take account of differences between institutions in variables (age, sex, total incapacity score) that affected survival, differences in survival rates remained significant $\left(\chi_{4}^{2}\right.$ df $\left.=11.80 ; p<0.05\right)$. The difference, however, now comprised a better rate of survival for patients who had been in private nursing homes. There was no significant difference in survival rates after adjustment for these factors among people who had been in geriatric, psychiatric, and acute hospitals or homes for the elderly.

\section{Discussion}

The much poorer survival rate found in this study for the population in NHS geriatric beds is what would be expected given the higher levels of dependency that occur in this setting. Similarly, given the nature of the population, so too would the more favourable survival figures enjoyed by residents of homes for the elderly.

Precise survival figures were closely similar to other British studies that have examined similar types of care. ${ }^{6-8}$ For example, in the study by Smith and Lowther of 200 admissions to a local authority residential home in Edinburgh 64\% were dead four years after admission. ${ }^{7}$ The corresponding figure for the population in homes for the elderly at the same time period after admission in the present study was $66 \%$, despite the fact that it used an estimate of survival from admission (the data were cross-sectional) while the former study was based on more recent admissions.

The gradient between increasing incapacity in each aspect of self care and higher levels of mortality is consistent with reports by other workers. ${ }^{910}$ Goldfarb et al studied a representative institutional sample of elderly people from homes for the aged, nursing homes, and state hopitals in New York City and found that incontinence of urine or faeces was a strong predictor of mortality. ${ }^{9}$ Their one year mortality for incontinent individuals (38\%) was similar to the figure (39\%) in the present study for frequently incontinent people in all types of care, and a clear gradient of mortality occurred between incontinent and continent old people in both studies.

A longer follow up of the New York population ${ }^{11}$ showed at three years survival figures similar to the present study for elderly people with incontinence and impairment of mobility.

Table 5 Estimated percentage survival (95\% confidence limits shown in brackets) to various times after admission to different types of care

\begin{tabular}{|c|c|c|c|c|c|c|}
\hline $\begin{array}{l}\text { Time from } \\
\text { admission }\end{array}$ & $\begin{array}{l}\text { NHS } \\
\text { geriatric beds }\end{array}$ & $\begin{array}{l}\text { NHS } \\
\text { psychiatric beds }\end{array}$ & $\begin{array}{l}\text { NHS } \\
\text { acute beds }\end{array}$ & $\begin{array}{l}\text { Homes for } \\
\text { the elderly }\end{array}$ & $\begin{array}{l}\text { Private nursing } \\
\text { homes }\end{array}$ & $\begin{array}{l}\text { All types of } \\
\text { care }\end{array}$ \\
\hline $\begin{array}{l}6 \text { months } \\
1 \text { year } \\
2 \text { years } \\
3 \text { years } \\
5 \text { years }\end{array}$ & $\begin{array}{l}61 \cdot 9 \\
(56 \cdot 2-67 \cdot 3) \\
49 \cdot 5 \\
(44 \cdot 3-54 \cdot 6) \\
37 \cdot 2 \\
(32 \cdot 8-41 \cdot 8) \\
27 \cdot 4 \\
(23 \cdot 8-31 \cdot 2) \\
10 \cdot 6 \\
(8 \cdot 2-13 \cdot 4)\end{array}$ & $\begin{array}{l}77 \cdot 2 \\
(67 \cdot 8-84 \cdot 8) \\
64 \cdot 4 \\
(55 \cdot 1-72 \cdot 7) \\
49 \cdot 2 \\
(41 \cdot 2-57 \cdot 1) \\
38 \cdot 7 \\
(32 \cdot 0-45 \cdot 8) \\
21 \cdot 8 \\
(16 \cdot 9-27 \cdot 5)\end{array}$ & $\begin{array}{l}75 \cdot 0 \\
(70 \cdot 2-79 \cdot 4) \\
67 \cdot 4 \\
(62 \cdot 4-72 \cdot 1) \\
59 \cdot 9 \\
(54 \cdot 7-64 \cdot 8) \\
53 \cdot 2 \\
(48 \cdot 0-58 \cdot 2) \\
49 \cdot 8 \\
(43 \cdot 1-56 \cdot 4)\end{array}$ & $\begin{array}{l}81 \cdot 0 \\
(75 \cdot 2-85 \cdot 9) \\
68 \cdot 8 \\
(63 \cdot 5-73 \cdot 7) \\
53 \cdot 9 \\
(49 \cdot 4-58 \cdot 3) \\
43 \cdot 3 \\
(39 \cdot 5-47 \cdot 1) \\
27 \cdot 0 \\
(24 \cdot 2-29 \cdot 8)\end{array}$ & $\begin{array}{l}80 \cdot 4 \\
(64 \cdot 7-91 \cdot 0) \\
64 \cdot 4 \\
(50 \cdot 8-76 \cdot 3) \\
53 \cdot 4 \\
(41 \cdot 7-64 \cdot 6) \\
40 \cdot 0 \\
(30 \cdot 7-49 \cdot 9) \\
23 \cdot 5 \\
(17 \cdot 1-30 \cdot 9)\end{array}$ & $\begin{array}{l}72 \cdot 3 \\
(69 \cdot 4-75 \cdot 0) \\
60 \cdot 9 \\
(58 \cdot 1-63 \cdot 7) \\
48 \cdot 4 \\
(45 \cdot 9-50 \cdot 9) \\
38 \cdot 5 \\
(36 \cdot 3-40 \cdot 7) \\
22 \cdot 5 \\
(20 \cdot 9-24 \cdot 2)\end{array}$ \\
\hline
\end{tabular}


In the present study most of the significant differences in survival between elderly people in different types of care disappeared when their different compositions in terms of functional capacity, age, and sex had been taken into account. Although there remained a slightly improved survival rate for patients in private nursing homes, elderly people who had been in the three types of NHS hospital or in homes for the elderly (and were similar in terms of these variables) experienced similar levels of mortality. From these data it seems unlikely that many disease processes "override" the prognostic effect of level of functional capacity, although it should be remembered that shorter stay patients would not be brought into this comparison and they are a group with a higher level of acute illness. Thus it seems that after the acute episode is over, loss of mobility or urinary incontinence (say) arising from, or coexisting with, a specific disease process is no more a powerful predictor of mortality than any other source.

Assessment of level of functional capacity in basic items of self care does not require complex procedures but a considered judgment by those staff immediately concerned with the old persons's care. It would seem a particularly appropriate means of summarising the status of populations when a range of disease problems are present. This is the situation par excellence in the elderly, and a classification according to function provides the basis for identifying homogenous groups that have ready plausibility and application in a multidisciplinary context. It may have a variety of uses-planning services and rehabilitation policies, evaluation of the components of care, and assessing the impact of individual institutional regimens.

We are grateful to all staff in NHS and social services premises in Leicestershire who helped with data collection and to the following individuals who acted as fieldwork coordinators: Professor S Brandon, Professor Michael Clarke, Dr M G Clarke, Dr R L Palmer, Mrs S Clarke, Mr M Baxandall, Dr A Williams, Mrs K Dodd, Dr W D Revill, Dr R W Kind, Miss A Odell, Mr J Dykes, Dr M Castleden, Mr J Henson, and Mr S Cardy. We also thank Mr John Woods for help with computing.
Financial support was provided by Leicestershire Health Authority.

Requests for reprints to: $\mathrm{Dr} \mathrm{L} J$ Donaldson. Department of Community Health, Clinical Sciences Building, Leicester Royal Infirmary, PO Box 65, Leicester LE2 7LX.

\section{References}

${ }^{1}$ Donaldson LJ, Clayton DG, Clarke M. The elderly in residential care: mortality in relation to functional capacity. J Epidemiol Community Health 1980; 34: 96-101.

${ }^{2}$ Warren MD, Knight R. Mortality in relation to the functional capacities of people with disabilities living at home.J Epidemiol Community Health 1982; 36: 220-3.

${ }^{3}$ Clarke M, Hughes AO, Dodd KJ, et al. The elderly in residential care: patterns of disability. Health Trends 1979; 11: 17-20.

4Greenwood M. The natural duration of cancer. Reports on Public Health and Medical Subjects 1926; 33: 1-26.

${ }^{5}$ Royal Statistical Society. The GLIM system-generalised linear interactive modelling manual. Oxford: Numerical Algorithms Group, 1978.

${ }^{6}$ Hodkinson HM, Hodkinson I. Death and discharge from a geriatric department. Age Ageing 1980; 9: 220-8.

${ }^{7}$ Smith RG, Lowther CP. Follow-up study of two hundred admissions to a residential home. Age Ageing 1976; 5: 176-80.

${ }^{8}$ Silver CP, Zuberi SJ. Prognosis of patients admitted to a geriatric unit. Gerontol Clin 1965; 7: 348-57.

' Goldfarb AI, Fisch M, Gerber IE. Predictors of mortality in the institutional aged. Diseases of the Nervous System 1966; 27: 21-9.

${ }^{10}$ Brauer E, Mackeprang B, Bentzon MW. Prognosis of survival in a geriatric population. Scand J Soc Med 1978; 6: $17-24$.

${ }^{11}$ Goldfarb AI. Predicting mortality in the institutionalised aged: a seven year follow-up. Arch Gen Psychiatry 1969; 21: 172-6. 